Article

\title{
Optimized Bioproduction of Itaconic and Fumaric Acids Based on Solid-State Fermentation of Lignocellulosic Biomass
}

\author{
Amparo Jiménez-Quero ${ }^{1,2}\left[\right.$, Eric Pollet ${ }^{1}\left(\mathbb{D}\right.$, Luc Avérous ${ }^{1, *} \mathbb{C}$ and Vincent Phalip ${ }^{1,3}$ \\ 1 BioTeam/ICPEES-ECPM, UMR CNRS 7515, Université de Strasbourg, 25 rue Becquerel, 67087 Strasbourg, \\ CEDEX 2, France; amparojq@kth.se (A.J.-Q.); eric.pollet@unistra.fr (E.P.) \\ 2 Division of Glycoscience, Department of Chemistry, School of Engineering Sciences in Chemistry, \\ Biotechnology and Health, KTH Royal Institute of Technology, 10044 Stockholm, Sweden \\ 3 Univ. Lille, INRA, ISA, Univ. Artois, Univ. Littoral Côte d'Opale, EA 7394-ICV—Institut Charles Viollette, \\ F-59000 Lille, France; vincent.phalip@polytech-lille.fr \\ * Correspondence: luc.averous@unistra.fr
}

Received: 9 January 2020; Accepted: 25 February 2020; Published: 27 February 2020

\begin{abstract}
The bioproduction of high-value chemicals such as itaconic and fumaric acids (IA and FA, respectively) from renewable resources via solid-state fermentation (SSF) represents an alternative to the current bioprocesses of submerged fermentation using refined sugars. Both acids are excellent platform chemicals with a wide range of applications in different market, such as plastics, coating, or cosmetics. The use of lignocellulosic biomass instead of food resources (starch or grains) in the frame of a sustainable development for IA and FA bioproduction is of prime importance. Filamentous fungi, especially belonging to the Aspergillus genus, have shown a great capacity to produce these organic dicarboxylic acids. This study attempts to develop and optimize the SSF conditions with lignocellulosic biomasses using $A$. terreus and $A$. oryzae to produce IA and FA. First, a kinetic study of SSF was performed with non-food resources (wheat bran and corn cobs) and a panel of $\mathrm{pH}$ and moisture conditions was studied during fermentation. Next, a new process using an enzymatic cocktail simultaneously with SSF was investigated in order to facilitate the use of the biomass as microbial substrate. Finally, a large-scale fermentation process was developed for SSF using corn cobs with $A$. oryzae; this specific condition showed the best yield in acid production. The yields achieved were $0.05 \mathrm{mg}$ of IA and $0.16 \mathrm{mg}$ of FA per gram of biomass after $48 \mathrm{~h}$. These values currently represent the highest reported productions for SSF from raw lignocellulosic biomass.
\end{abstract}

Keywords: lignocellulosic biomass; solid-state fermentation; enzymatic hydrolysis; aerated bioreactor; Aspergillus oryzae

\section{Introduction}

Solid-state fermentation (SSF) has emerged in the last decades as a promising industrial process for several products, especially using agricultural byproducts as the substrates [1,2]. SSF involves the growth of a microorganism on solid particles in the quasi absence of free water, and the majority of processes are performed by filamentous fungi under aerobic conditions [3]. The substrates used in SSF are often the source of nutrients for the microorganisms, and the inter-particle spaces allow gas and nutrients exchange between fungal hyphae and the medium. Fungi also behave as biocatalysts for the bioconversion of the substrates into specific target products such as bio-based fuels, commodity chemicals, enzymes, bioactive compounds, or food products [4].

SSF offers several advantages compared to submerged fermentation (SmF) such as high volumetric productivity, product concentration, simpler and smaller bioreactors because of the minimal free water, 
a lower sterilization cost, less generation of effluents (reduced cost of effluent treatment), and easier aeration due to lower density of the corresponding medium with high porosity [5,6]. Finally, the conditions of SSF mimic the natural environments of the filamentous fungi. However, the SSF process is slower compared to $\mathrm{SmF}$, and all fermentation conditions cannot be controlled precisely. The main factors affecting fungal growth and metabolism in SSF are the selection of a suitable microorganism and substrate for the targeted generation of products, the pre-treatment of the substrate, the moisture, the temperature, and the removal of metabolic heat and gas transfers [7].

One of the most interesting biotechnological applications of SSF is the production of commodity chemicals [8,9]. The biosynthesis of chemicals from biomass creates a sustainable alternative to the conventional chemical synthesis based on fossil resources $[10,11]$. In the last two decades, many molecules produced from biomass with a large range of applications have been described [12,13]. Many of these building blocks are organic acids because of their capacities to generate high-value products for widespread industries such as food, pharmaceuticals or polymers [14-16]. The biosynthesis of by filamentous fungi has been studied extensively, and Aspergilli are often used for industrial production [17].

Among the organic acids, fumaric and itaconic acids (FA and IA, respectively) are included on the DOE's (Unites State Department of Energy) list as part of the top twelve biomass-derived platform chemicals [12]. Both acids are polyfunctional building blocks that can be polymerized for instance, to give homo- or co-polymers for applications in textile, chemical, and pharmaceutical industries. IA can be used to replace acrylic acid, an important and rather costly chemical that is non-renewable so far, while FA can be used as food additive and in psoriasis treatment $[14,16]$. These acids are part of the tricarboxylic acid (TCA) cycle, FA being a direct intermediate in the cycle and IA a derivate of cis-aconitate acid, and both are produced under aerobic conditions. Currently, the industrial production of FA is via catalytic isomerization of fossil-based maleic acid. However, FA could also be produced biologically as an intermediate of the TCA cycle that is present in most aerobic organisms. Laboratory-scale fermentations with Rhizopus oryzae have shown interesting productivities in SmF of lignocellulosic biomass, around $0.35 \mathrm{~g} / \mathrm{g}$ corn straw [18,19]. IA is produced industrially by Aspergillus terreus in SmF with glucose as the principal carbon and energy source to a yield of $100 \mathrm{~g} / \mathrm{L}$ [20-22]. The biosynthesis involves the action of the cis-aconitate decarboxylase (CAD) enzyme to transform the cis-aconitate into itaconate. The presence of CAD in A. terreus has been demonstrated in different studies, but this enzyme is also present in another Aspergillus species; A. oryzae [23,24]. This aerobic, filamentous fungus is frequently used in SSF processes due to its capacity to hydrolyze the lignocellulosic substrates by enzymatic degradation [25]. Nevertheless, the production of IA and FA by SSF with lignocellulosic biomass has not been studied extensively in the literature. A method of SSF using sugarcane pressmud as a support for IA production, which yielded $0.0003 \mathrm{~g} \mathrm{~kg}^{-1} \mathrm{~h}^{-1}$, was patented in 2001 [26]. In this case, the main carbon source for the acid production has been added as liquid medium and the remaining sucrose for the sugarcane was a supplementary source. A maximum productivity of $0.021 \mathrm{~g} \mathrm{~kg}^{-1} \mathrm{~h}^{-1}$ of FA was reported via SSF of corn distiller grains by R. oryzae [27]. In a previous study, we have shown the capacity of $A$. terreus and $A$. oryzae to produce both acids by SSF process $[28,29]$. The yields obtained by $A$. oryzae from corn cobs were the most interesting, with 0.05 and $0.18 \mathrm{mg}$ acid/g biomass of IA and FA, respectively. As expected, both productivities were lower than values reported from $\mathrm{SmF}$ processes utilizing soluble sugars in liquid media.

The aim of this work was to optimize the bioproduction of IA and FA in SSF by two Aspergillus species (A. terreus and A. oryzae) using lignocellulosic biomass as a non-food carbon source (wheat bran and corn cobs). As it is a complex and recalcitrant structure, lignocellulosic biomass is often predigested to be used as a sugar source for fermentation [30]. The bioconversion is carried out by enzymes produced under specific conditions by many microorganisms [31]. This saccharification process requires several hydrolytic enzymes such as cellulases, hemicellulases, xylanases, etc. [32]. The biomass pretreatment is one of the most expensive part of the lignocellulosic material conversion in an industrial scale. Therefore, the process could be coupled with the fermentation in a simultaneous saccharification-fermentation 
step, in order to improve the process yields. The study of this simultaneous process can open the possibility to decrease cost and time for an industrial activity in future. Several factors were studied to enhance organic acid production yields ( $\mathrm{pH}$, moisture content, enzyme hydrolysis) and large-scale fermentations were tested using these optimized factors.

\section{Results}

\subsection{Solid-State Fermentation Kinetics}

Fermentations were performed for both fungal species using both biomasses, wheat bran, and corn cobs. Organic acid production and fungal growth were studied. The determination of protein secretion level showed that $A$. terreus and $A$. oryzae present different development trends on wheat bran and corn cobs, Figure 1 . The growth of $A$. oryzae on wheat bran reached a plateau after $120 \mathrm{~h}$ whereas A. terreus grew more slowly and regularly for more than $200 \mathrm{~h}$ on both substrates. Both species grew better on wheat bran than on corn cobs, as reported before in our previous studies, where both fungi species were capable of producing higher amounts of hydrolytic enzymes on wheat bran biomass [28,29]. These results were also confirmed by visual observations. More FA was produced from wheat bran with 0.8 and $0.6 \mathrm{mg} / \mathrm{g}$ biomass for $A$. terreus and A. oryzae, respectively, at the end of the fermentation with a regular increase in the yields. On corn cobs, FA production displayed a completely different profile, with a maximum yield after $48 \mathrm{~h}(0.14$ and $0.12 \mathrm{mg} / \mathrm{g}$ for $A$. terreus and A. oryzae, respectively) and then a regular decrease.
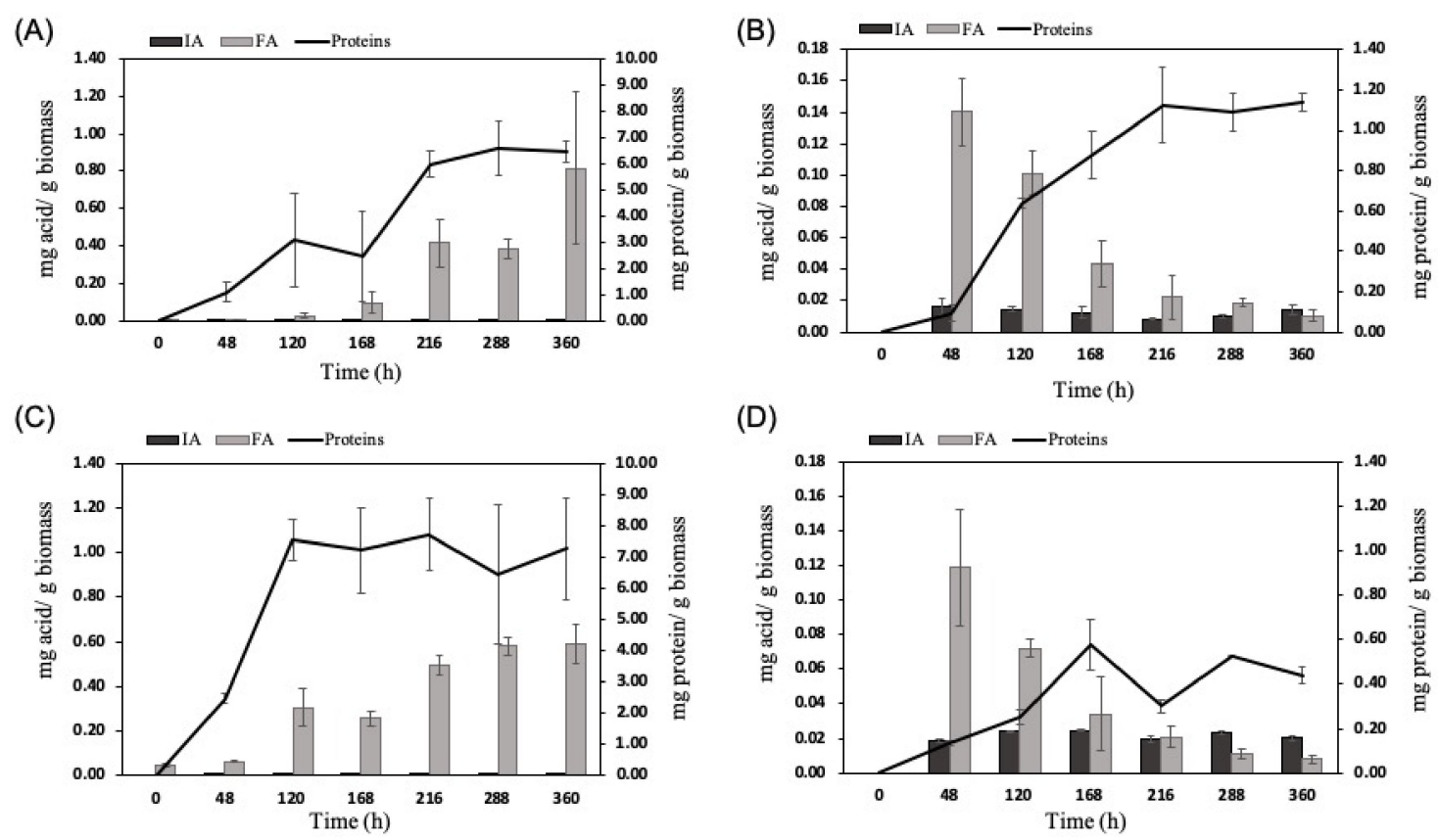

Figure 1. Fermentation kinetics on lignocellulosic biomasses: itaconic acid (IA) and fumaric acid (FA) yields and protein production (fungal growth) from wheat bran $(\mathbf{A}, \mathbf{C})$ and corn cobs (B,D) by A. terreus (A and B, respectively) and by A. oryzae (C and D, respectively).

Although the fungal growth was significantly higher on wheat bran, IA was produced only on corn cobs for both fungi, Figure 1. The different composition of both biomasses [28] may explain this behavior. A maximum IA yield of $0.025 \mathrm{mg} / \mathrm{g}$ corn cobs was produced by A. oryzae at $168 \mathrm{~h}$ of fermentation. At the same fermentation time, A. terreus produced half of this amount $(0.012 \mathrm{mg}$ IA $/ \mathrm{g}$ biomass). The fungal biomass of $A$. oryzae was 15 times lower on corn cobs than on wheat bran and almost 2.5 times lower than the one of $A$. terreus on corn cobs. 


\subsection{Optimization of the SSF Steps}

After testing the fermentations with both biomasses and fungi, the optimization steps were performed in two different ways. Firstly, a study with varying $\mathrm{pH}$ and humidity levels was carried out with corn cobs, to further improve the IA production. Secondly, an optimization of $A$. oryzae fermentation (displaying the highest IA production yield) was performed both on wheat bran and corn cobs by adding an enzyme cocktail to better hydrolyze the lignocellulosic biomasses. That could allow a more efficient conversion of accessible fermentable sugars in order to increase the yield of the fermentation products.

\subsubsection{Effect of $\mathrm{pH}$ and Moisture Level}

Optimum $\mathrm{pH}$ and moisture level are crucial factors in SSF processes to obtain maximum yields of the products of interest $[6,33]$. The initial and previously tested conditions for corn cob fermentation (Section 2.1.) were $\mathrm{pH} 5$ for the inoculation and $90 \%$ humidity. To optimize the $\mathrm{pH}$ and moisture conditions, five different $\mathrm{pH}$ values and five different moisture levels were evaluated for the inoculation step of the biomass culture, Figure 2 and Figure S1 in Supplementary Materials.

(A)

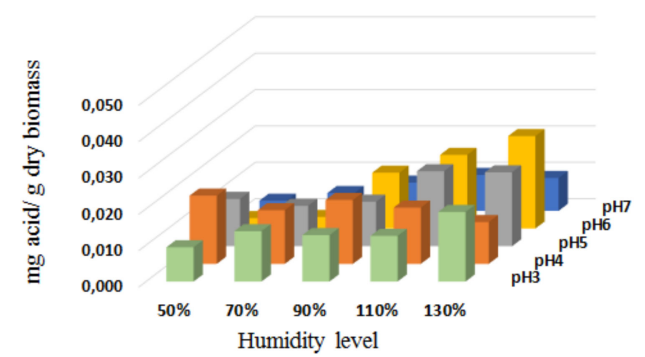

(C)

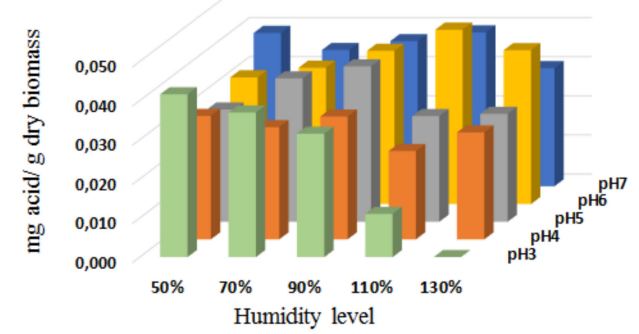

(B)

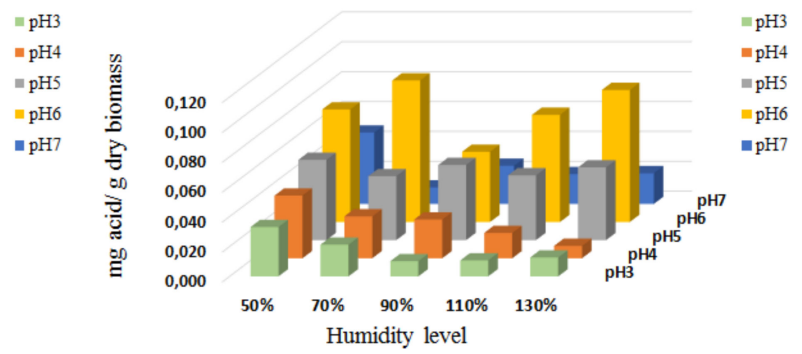

(D)

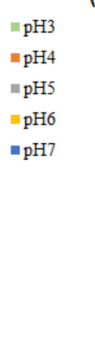

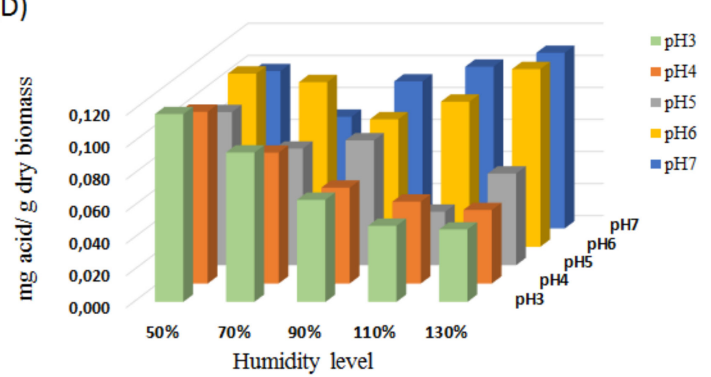

Figure 2. Solid-state fermentation (SSF) on corn cobs at different $\mathrm{pH}$ and moisture levels by $A$. terreus (IA and FA yields: $\mathbf{A}$ and $\mathbf{B}$, respectively) and A. oryzae ( $\mathbf{C}$ and $\mathbf{D}$, respectively).

For A. terreus, both acids were produced with higher yields at $\mathrm{pH} 6$, as reported before [28,34]. The moisture content influenced the IA and FA production differently. The best IA production, $0.025 \mathrm{mg}$ IA/g corn cobs, was observed at $\mathrm{pH} 6$ and 130\% humidity (Figure 2A) i.e., a doubling of the production compared to the initial conditions ( $\mathrm{pH} 5$ and 90\% humidity). FA was produced at a yield of $0.095 \mathrm{mg} / \mathrm{g}$ biomass (pH 6 and 70\% humidity), which is also almost twice the production at initial conditions (Figure 2B). For both acids, a clear trend is that a neutral $\mathrm{pH}(\mathrm{pH}=7)$ seems too high (Figure 2A,B). This observation is in good agreement with previous results obtained for SmF [31].

A. oryzae also showed a preference for $\mathrm{pH}$ 6, for the production of both acids (Figure 2C,D). In the case of IA, the highest yield was $0.045 \mathrm{mg} / \mathrm{g}$ biomass at $110 \%$ humidity (Figure 2C), which is slightly higher than the yield under the initial conditions ( $0.039 \mathrm{mg} \mathrm{IA} / \mathrm{g}$ biomass) and almost twice the yield obtained with $A$. terreus. Under the same conditions ( $\mathrm{pH} 6,110 \%$ humidity), $0.091 \mathrm{mg} \mathrm{FA} / \mathrm{g}$ was produced (Figure 2D). It is not the highest yield since at 130\% humidity, the production was even higher $(0.111 \mathrm{mg} / \mathrm{g}$ biomass). 


\subsubsection{Enzymatic Hydrolysis}

The enzymatic cocktail was obtained by SSF of wheat bran by A. oryzae, as shown in previous studies [29], the solid fermentation of the biomass allows to produce higher protein content with specific lignocellulolytic enzymes for biomass degradation. The cocktail can be store at $-20{ }^{\circ} \mathrm{C}$ and used for simultaneous SSF.

The enzyme cocktail produced by A. oryzae showed the best enzymatic activity for endoxylanases (Table 1), which are responsible for hemicellulose hydrolysis. Hemicellulose is the most abundant part of corn cobs $[35,36]$. Moreover, cellulase and xyloglucanase activities were also found, suggesting an efficient biomass digestion. When the enzymatic cocktail was used for simultaneous saccharification-fermentation of corn cobs, $A$. oryzae rapidly secreted proteins (i.e., it grew) in the first $20 \mathrm{~h}$, and a plateau was subsequently reached (Figure 3B) approximately at the same level as with the raw biomass (Figure 1D). Surprisingly, with the treated wheat bran (Figure 3A), the fungi secreted half of the proteins compared to the untreated biomass (Figure 1C). Moreover, the treatment had a dramatic negative effect on the production of FA from wheat bran (Figure $3 \mathrm{~A})$ with a yield $(0.08 \mathrm{mg} / \mathrm{g}$ biomass) almost 8 times lower than without pretreatment $(0.6 \mathrm{mg} / \mathrm{g}$ of biomass) (Figure 1C). In contrast, for corn cobs, the FA yield was feebly increased to $0.15 \mathrm{mg} / \mathrm{g}$ biomass. The profile of FA production from corn cobs (Figure 3B) was similar to the one without the enzyme cocktail (Figure 1D) with a yield reaching a maximum (after ca. $50 \mathrm{~h}$ ) followed by a decay.

Table 1. Enzymatic activities (in $\Delta \mathrm{OD} / \mathrm{g}^{*} \mathrm{~min}^{*}$ ) of the enzymatic cocktail obtained from SSF of wheat bran by A. oryzae.

\begin{tabular}{cc}
\hline$\alpha$-Amylase activity & 18.10 \\
Cellulase activity (cellulose) & 4.69 \\
Endoxylanase activity & 70.30 \\
Cellulase activity (xyloglucan) & 10.11 \\
\hline
\end{tabular}

Enzyme activities were expressed in arbitrary units corresponding to optical density variations $(\triangle \mathrm{OD})$ per minute and per gram of biomass, due to the unknown extinction coefficient of AZCL substrate (Megazymes, Ireland).

(A)

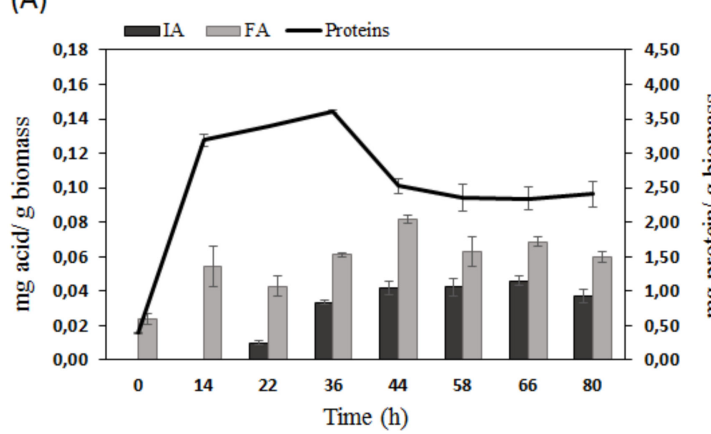

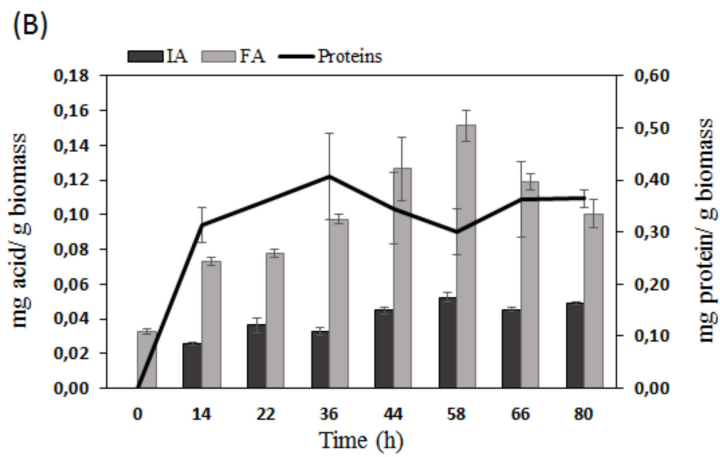

Figure 3. Kinetics of simultaneous saccharification and fermentation of wheat bran (A) and corn cobs (B) by A. oryzae.

The best contribution of the enzyme cocktail was observed for the production of IA. According to our knowledge, the use of such enzymatic cocktail allowing IA production from wheat bran was reported for the first time in this study. IA production was detectable after $22 \mathrm{~h}$, and a maximum yield of $0.046 \mathrm{mg} / \mathrm{g}$ biomass was obtained after $66 \mathrm{~h}$ (Figure 3A). With corn cobs, IA production is clearly detected earlier ( $14 \mathrm{~h}$ ), and a yield of $0.052 \mathrm{mg} / \mathrm{g}$ biomass was achieved (Figure 3B) that was twice the maximum yield produced without enzymatic treatment for optimized $\mathrm{pH}$ and moisture level, Figure 2C. 


\subsection{Kinetics of SSF with Optimized Conditions}

According to previous results, the optimum fermentative process was $80 \mathrm{~h}$ at $\mathrm{pH} 6$ and $110 \%$ humidity. Figure 4 presents the glass flasks and shows the development of $A$. oryzae through the fermentation (with a green color indicating a high spore concentration). The fungus grew progressively during the fermentation until $0.22 \mathrm{mg}$ of protein/g of biomass was obtained, as shown earlier (at pH 5 and $90 \%$ moisture level) at the same time of fermentation (Section 2.2.1). In relatively good agreement, FA production was only slightly enhanced $(+10 \%)$ with a maximum yield of $0.16 \mathrm{mg} / \mathrm{g}$ biomass within $48 \mathrm{~h}$ (Figure 4). However, for IA, the enhancement was higher because the production was more than doubled ( $0.051 \mathrm{mg} / \mathrm{g}$ biomass) after $48 \mathrm{~h}$ and higher $(0.061 \mathrm{mg} / \mathrm{g})$ after $80 \mathrm{~h}$ (factor 2.4$)$. As generally described for fungi, $A$. oryzae metabolism is greatly influenced by $\mathrm{pH}$ and the humidity level at the start of the fermentation step $[37,38]$.

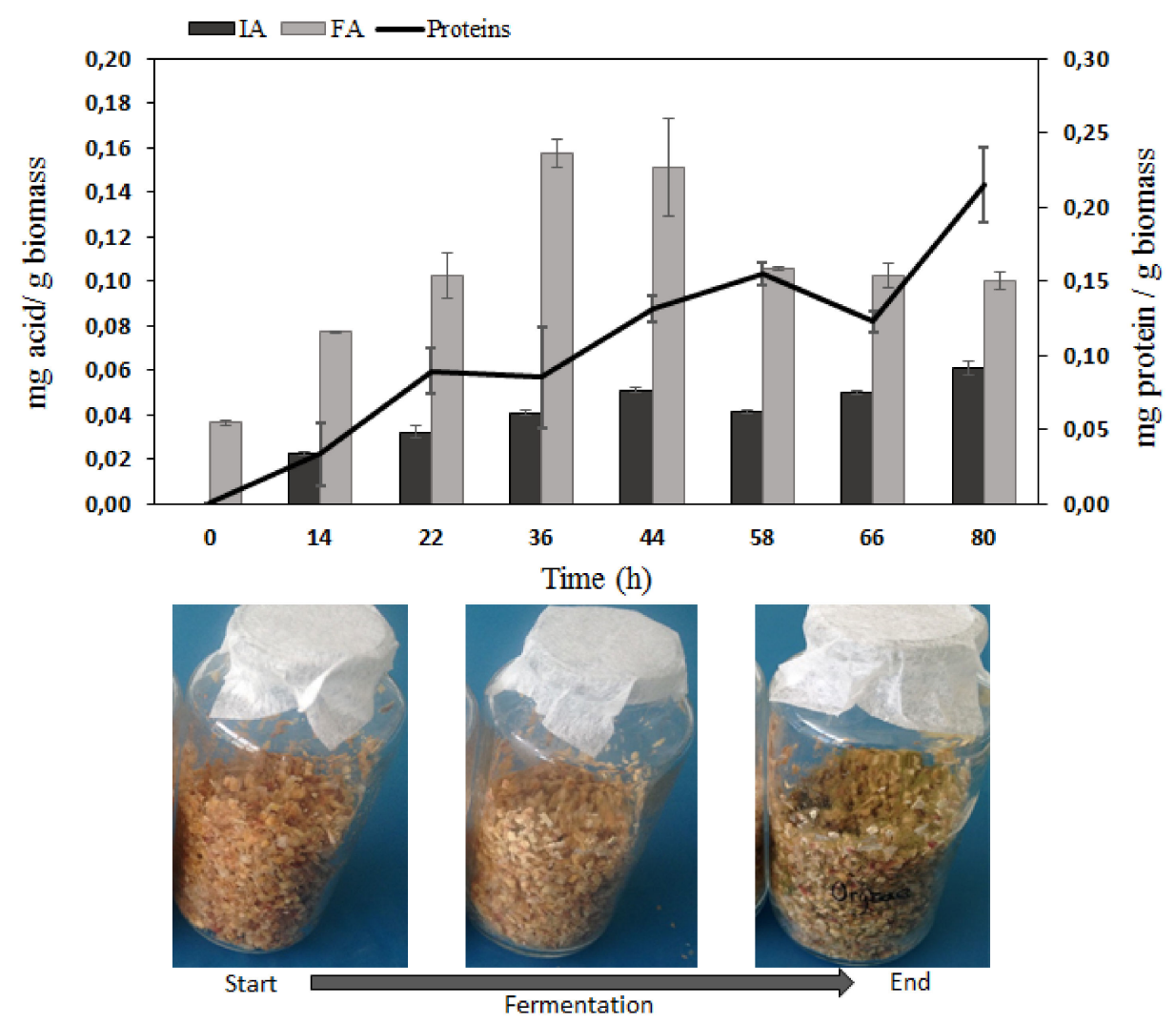

Figure 4. Kinetics of SSF on corn cobs by A. oryzae under optimized conditions (pH 6 and $110 \%$ moisture).

\subsection{Larger Scale Fermentation}

To develop and analyze the scaling up, the fermentation was performed with $200 \mathrm{~g}$ of corn cobs i.e., 20 times more than for the previous glass flasks experiments. The optimized conditions of $\mathrm{pH}$ and moisture (i.e., $110 \%$ moisture and $\mathrm{pH}=6$ ) were applied for the scaled-up fermentation. Aeration plays an important role in SSF for the transfer of oxygen and the evacuation of the carbon dioxide produced. Aeration is also used (Figure 5) to dissipate the metabolic heat generated by fermentation [39]. The mixture of substrates (solid lignocellulose particles and fungal mycelium) also helps to equilibrate the gas exchange, temperature, and moisture level [3], avoiding the disruption of the mycelial-substrate contact, which is particularly important for A. oryzae, for instance, to produce the degrading enzymes to hydrolyze the biomass. 


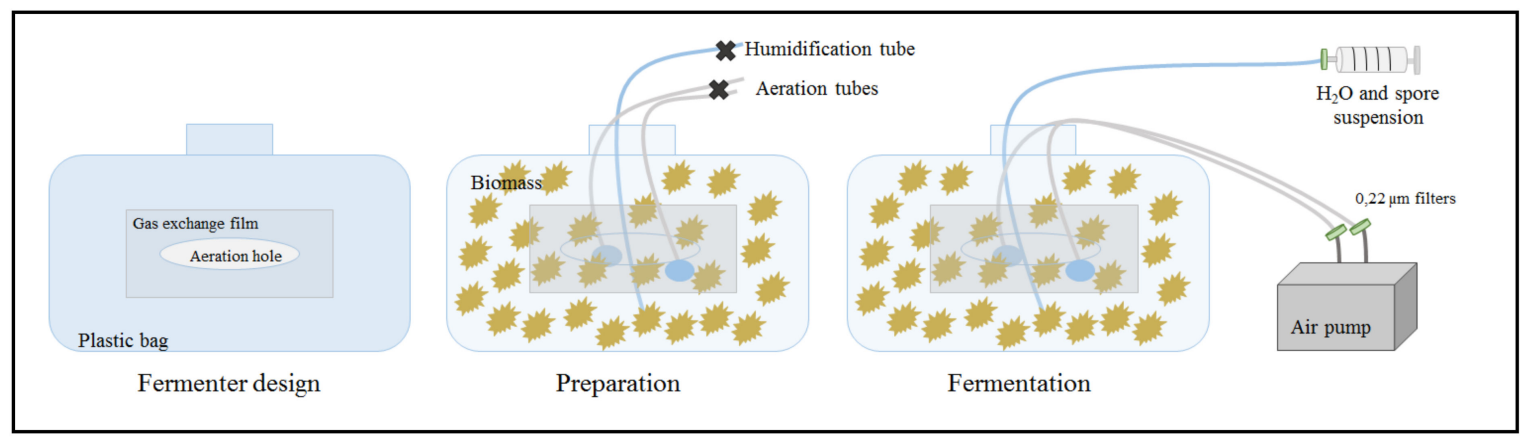

Figure 5. Illustration of aerated plastic bag fermenter (at left), made from autoclavable biohazard bags in polypropylene with an aeration hole covered by a gas exchange Miracloth film (Millipore, USA). Prior to autoclaving (middle), corn cobs were introduced as well as the air and humidification tubes (autoclavable tubes in PVC used for the liquid bioreactor). Right: Operative fermenter with aeration and the inoculum to be injected.

Two different processes were used to test the influence of both aeration and mixing. A monolayer reactor presenting the same conditions as the glass flasks except for size was compared with an aerated plastic bag fermenter. The plastic bag fermenter was gently mixed on a rocker shaker and distilled water was added in a timely manner to equilibrate the moisture level. The fungal growth was clearly different between the two fermenters (Figure 6). The aerated plastic bag yielded nearly twice the proteins concentration $(0.26 \mathrm{mg} / \mathrm{g}$ biomass $)$ as the monolayer fermenter $(0.15 \mathrm{mg} / \mathrm{g}$ biomass $)$ at the end of the fermentation. Compared with the glass flask fermentation $(0.22 \mathrm{mg}$ protein/g biomass, Figure 4) the monolayer fermenter produced less protein whereas the aerated one displayed an amount of protein similar to the small-scale fermentation. This difference in fungal growth was also obvious in observing $A$. oryzae sporulation, which occurred earlier for the monolayer fermenter (until the second fermentation day) than for the aerated fermenter. This premature sporulation indicates that mycelial development was interrupted by inadequate conditions. The aeration and the loss of humidity correction increased the fungal development and also delayed the sporulation.

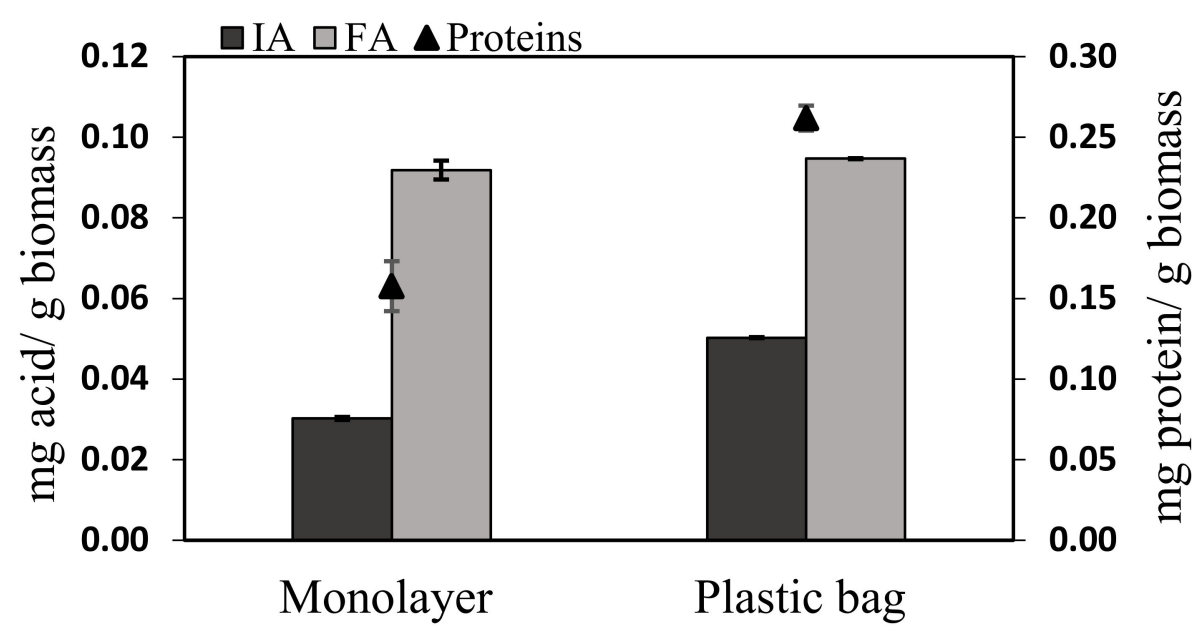

Figure 6. SSF in larger scale fermenters of A. oryzae from corn cobs: Organic acid productions and protein secretion (growth).

The FA production was not affected by the different conditions ( $0.09 \mathrm{mg} / \mathrm{g}$ biomass in both reactors), probably because $96 \mathrm{~h}$ of fermentation was not an optimized time to recover FA as shown in the glass flask (Figure 4) where the maximum FA yield was produced at $36 \mathrm{~h}$. Conversely, IA production was $60 \%$ higher in the aerated fermenter (Figure 6) than in the monolayer reactor. 


\section{Discussion}

From the SSF kinetics experiments, we can conclude that IA production was inversely linked to growth. Both acid yields were lower than the yields from the current SmF [31-33], then the optimization of the fermentative conditions is necessary to enhance the acid production. During the optimization steps, we could observe how low moisture content causes slower enzyme secretion from the fungus due to the lower solubility of the nutrients and the low level of growth [37,38] (Figure S2 in Supplementary Materials). However, acidic $\mathrm{pH}(3-5)$ and low moisture often allowed better production of the acids (Figure 2B,D). This behavior is not observed at higher pHs. These observations are in agreement with the fact that in SSF, pH variation significantly impacts the production and the stability of the enzymes [5,39], with several enzymes responsible for biomass hydrolysis during growth. The $\mathrm{pH}$ effect on the organic acid production was in accordance with the simultaneous fermentation and enzymatic hydrolysis study performed previously [29]. Even if the enzymatic cocktail did not improve the growth of the fungus nor FA production, the cocktail created better conditions to produce IA. FA is an intermediate metabolite of fungal fermentation, and its production is directly linked with the development of the microorganism unlike IA, a secondary metabolite [34]. The time lag between growth and IA production is perfectly consistent with a secondary metabolite behavior. These results showed the importance of a separated optimization of FA and IA production, as well as the time of recovery of the carboxylic acids during the fermentation, especially from a continuous production perspective.

The acid yields for the simultaneous saccharification and fermentation process were higher in comparison with the best results obtained for optimized $\mathrm{pH}$ and moisture ( $\mathrm{pH}=6$ and $110 \%$ humidity) with corn cobs and A. oryzae, (Figure 2C,D). However, the production of the enzyme cocktail required four additional days for the entire process. Therefore, the most interesting strategy for the acid production was the kinetic fermentation of corn cob biomass by A. oryzae with the optimized conditions of $\mathrm{pH}$ and humidity. The kinetic curves showed the differential production over time for both acids, leaving the possibility to improve and optimize the time production of the acids if focusing exclusively on one of them. In this case, the $\mathrm{pH}$ and the moisture should be adapted from the previous results (Figure 2 and Figure S1 in Supplementary Materials).

The literature is deficient concerning SSF of FA and IA without biomass pretreatment. For IA, a mutant of $A$. terreus displays a productivity of $0.0003 \mathrm{mg} / \mathrm{g}$ h with sugarcane pressmud supplemented with sugars and nutrients [26]. The result obtained in this study was more than two times higher $(0.00076 \mathrm{mg} / \mathrm{g} \mathrm{h})$ by A. oryzae (novel IA producer) with a lignocellulosic substrate without any nutrient addition [29]. Our study can contribute to further optimization on the fermentation conditions ( $\mathrm{pH}$, humidity, and aeration level), that combined with new studies using metabolic engineered microorganisms $[40,41]$ providing better yields in IA production from lignocellulosic materials.

Regarding the larger scale fermentation in the plastic bag prototype reactor, the improvement in acid production could be explained by the better supply of oxygen and moisture in the fermenter. Indeed, IA fermentation is strictly aerobic, and previous studies showed that a gain in dissolved oxygen and agitation induced higher yields [42,43]. The moisture level could affect the IA production. Below $70 \%$ humidity, the nutrient transfers are limited, and the metabolism is affected [44]. In our experiment, water addition along with aeration may allow better fermentation conditions of the air-solids-water to enhance IA production. Most of these factors were studied for A. terreus, long known as an IA producer. However, for $A$. oryzae, conditions still need further optimization. Even if the IA yield obtained in the aerated fermenter $(0.05 \mathrm{mg} / \mathrm{g}$ biomass) was similar to the small glass flask, the final production was multiplied by 20. Of course, the yields obtained in this work are still far from the industrial scale target, and further work in optimizing the fermentation conditions and down-stream processing have to be carried out. Anyway, A. oryzae, which showed the most interesting enzymes production for biomass degradation, seems to be an excellent candidate for further studies. 


\section{Materials and Methods}

\subsection{Feedstock and Microorganisms}

Two agricultural waste biomasses used as non-food carbon sources were wheat bran and corn cobs obtained from Comptoir Agricole (Lauterbourg, France). The lignocellulosic material was milled (SX 100, Retsch) to obtain particles that were $0.5-1 \mathrm{~mm}$ in size. The water activity (Aw) was measured on $1 \mathrm{~g}$ of dry substrate by an Aw meter Fast-lab (GBX, France).

A. terreus (DSM 826) was provided by the Deutsche Sammlung von Mikroorganismen und Zellkulturen (DSMZ, Braunschweig, Germany). A. oryzae (UMIP 1042.72) was provided by the Fungal Culture Collection of the Pasteur Institute (France). The strains were revived on potato dextrose broth medium (PDB) for 5-6 days at $25^{\circ} \mathrm{C}$. The microorganisms were then grown and sporulated on potato dextrose agar (PDA). The spore suspensions were harvested from 5-6-day-old PDA plates with $0.2 \%$ $(v / v)$ Tween-80. The spores were counted using a Malassez counting chamber and stored at $-20{ }^{\circ} \mathrm{C}$.

\subsection{Initial SSF Step}

In glass flasks, $5 \mathrm{~g}$ of solid substrate were autoclaved at $121^{\circ} \mathrm{C}$ and 3 bars, for $20 \mathrm{~min}$. The substrates were inoculated with spore suspensions to have an initial concentration of $10^{6} \mathrm{spores} / \mathrm{g}$ of substrate. Initial moisture was adjusted to $120 \%$ for wheat bran and $90 \%$ for corn cobs (both corresponding to an Aw near 1). After thorough mixing, the flasks were covered with a porous adhesive film (VWR, Radnor, PA, USA) and incubated at $30^{\circ} \mathrm{C}$ for 6 days. Unless specified otherwise, these fermentation conditions were maintained throughout the study. All the experiments were conducted in duplicate. After fermentation, the samples were recovered by mixing the fermented substrate with sterilized distilled water $(7 \mathrm{~mL} / \mathrm{g}$ of initial dry substrate). The preparations were centrifuged ( $8000 \times g$ for $15 \mathrm{~min})$ to eliminate residual solids. Then, another centrifugation step was performed on the supernatants to remove mycelia and spores $(13,600 \times g$ for $30 \mathrm{~min})$. The resulting solution was finally filtered through a $0.2 \mu \mathrm{m}$ membrane. The samples were analyzed by high-performance liquid chromatography (HPLC, Waters, Milford, MA, USA) and were stored at $-20^{\circ} \mathrm{C}$ for additional analysis.

\subsection{1. $\mathrm{pH}$ and Humidity Level Optimization}

The initial $\mathrm{pH}$ and humidity levels were varied to screen the best conditions for organic acid production. Citrate-phosphate buffer solutions, $\mathrm{pH} 3$ to 7 , were prepared. The moisture content was set at 50,70, 90, 110, and $130 \mathrm{v} / \mathrm{w}$. Five $\mathrm{pH}$ conditions were crossed with five relative humidity level, generating 25 different conditions performed with biological duplicates in SSF.

\subsubsection{Enzyme Production for Biomass Hydrolysis}

The enzymatic cocktail preparation was performed in a plate with $250 \mathrm{~g}$ of wheat bran by A. oryzae. The inocula were prepared with $300 \mathrm{~mL}$ of Tris buffer at $\mathrm{pH} 10$ to achieve a final spore concentration of $10^{6}$ per $g$ of biomass, and the incubation temperature was $25^{\circ} \mathrm{C}$ during the 4 days. The enzymatic cocktail was recovered with $1500 \mathrm{~mL}$ of sodium phosphate buffer at $\mathrm{pH} 6$ and filtered with a Vivaflow 200 system (Sartorius, Göttingen, Germany). The cocktail was stored at $4{ }^{\circ} \mathrm{C}$, and enzyme activities were determined.

\subsection{Scale-Up Steps}

Fermentation at a higher scale, with $200 \mathrm{~g}$ of biomass, was performed in two different types of reactor. A monolayer reactor consists of a glass plate covered with a gas exchange Miracloth film (Millipore, Temecula, CA, USA). The second reactor is a prototype of an aerated reactor (Figure 5). This fermenter was made from an autoclaved polypropylene laboratory bag with a central opening covered with a gas exchange film of Miracloth. Two PVC tubes were introduced and connected to stone ceramic air diffusers ( $3 \mathrm{~mm}$ in diameter). Another PVC tube was added for inoculation and 
double distilled water addition. The entire reactor was autoclaved with the biomass inside. During fermentation, double distilled water was added at the rate of $11 \mathrm{~mL}$ per day to keep the moisture constant (considering 10\% evaporation/day). The aeration was provided by an air pump AC-9906 (Resun, Shenzhen, China) at a flow rate of 840 L/hour. A rocker mixer (ThermoFisher, Waltham, MA, USA) was used to shake the fermenter in order to uniformly add the water to the biomass. The influence of these controlled conditions of air and moisture content on the acid production could be studied for the plastic bag reactor but not for the monolayer reactor.

\subsection{Analytical Procedure}

\subsubsection{Mycelial Growth (Protein Assays)}

To determine the fungal proteins produced during the fermentation, Bradford method was used [45]. All the samples were centrifuged and filtered $(0.22 \mu \mathrm{m})$ before analysis to eliminate the spores. The protein assay was calibrated using BSA (bovine serum albumin) as the standard.

\subsubsection{Organic Acid Assays}

A chromatographic system based on a 616 pump, a 2996 photodiode array detector operating in a range of 200 to $450 \mathrm{~nm}$, and a 717 Plus autosampler (Waters, Milford, MA, USA) controlled by Empower 2 software (Waters, Milford, MA, USA) was used to analyze the samples, as previously described [29]. The columns were calibrated using commercial IA and FA samples with a 99.9\% purity (Sigma-Aldrich, San Luis, MO, USA) and a UV measurement at $205 \mathrm{~nm}$. Each sample was supplemented with $10 \mathrm{ppm}$ IA or FA as the internal standard to confirm the acid production.

\subsubsection{Enzyme Activity Assay}

Chromogenic substrates, azurine-crosslinked (AZCL) polysaccharides such as AZCL-HE-cellulose, AZCL-xylan, AZCL-xyloglucan, or AZCL-amylose (Megazyme, Bray, Ireland), were used to measure the enzyme cocktail activity. The samples were collected and analyzed as previously described [28], by spectrophotometry determining absorbance of the supernatant at $595 \mathrm{~nm}$ that corresponds with the solubilization of dyed compounds (AZCL) by the enzymes present in the cocktail.

\section{Conclusions}

The IA production process appears to be ideally amenable to SSF conditions, as demonstrated in this work. However, the fermentation conditions still need further optimization to provide yields similar to the yields obtained by submerged fermentation, considering the use of lignocellulosic substrates. Additionally, the use of a novel species, A. oryzae (which is used industrially for enzyme production) opens up the possibility of creating a biorefinery process for the production of both organic acids and enzymes. The use of agricultural wastes and cheap and non-food substrates in the bioprocess could lower IA production costs and could therefore promote the use of bio-based IA in the polymerization process to replace petroleum-derived polymers. Furthermore, the simultaneous production of another organic acid as FA by Aspergillus species can open the possibility to adapt the use of different lignocellulosic biomass for particular building blocks production. Moreover, in the case of downstream purification processes for both IA and FA, the opportunity of co-polymerization could be an interesting case of study. Anyway, the results showed that time production as well as the fungi needs can differ between IA or FA production, and specific individual optimization for SSF should also be done. Moreover, further studies need to be performed in the use of commercial enzymatic cocktails to improve the production yields, but also to understand the need for better biomass hydrolysis in $\mathrm{SSF}$. In this sense, $A$. oryzae seem to be a great candidate for commercial enzymes production. One possibility could be the use of metabolic engineering to guaranty the strong lignocellulolytic enzyme release combined with specific metabolic route for IA or FA, exclusively. In this work, the organic acids yields were slightly lower than those obtained in previous studies. However, the global time-lapse of 
the process was greatly decreased considering that no previous pretreatment steps were preformed, or enzymatic cocktails were collected.

Supplementary Materials: The following are available online. Figure S1. SSF on corn cobs at different $\mathrm{pH}$ and moisture levels by $A$. terreus and $A$. oryzae; Figure S2. Fungal growth (proteins productions) under different $\mathrm{pH}$ and moisture conditions.

Author Contributions: Conceived and designed the experiments, all authors; performed the experiments, A.J.-Q.; analyzed and interpreted the data, all authors; wrote the paper. All authors have read and agreed to the published version of the manuscript.

Funding: This work has received funding from the European Union's 7th Framework Program under grant agreement n ${ }^{\circ} 311815$ (SYNPOL Project).

Conflicts of Interest: The authors declare no conflict of interest.

\section{References}

1. Pandey, A. Solid-state Fermentation in Biotechnology: Fundamentals and Applications; Asiatech Publishers: New Delhi, India, 2001.

2. Hölker, U.; Lenz, J. Solid-state fermentation-Are there any biotechnological advantages? Curr. Opin. Microbiol. 2005, 8, 301-306. [CrossRef] [PubMed]

3. Hölker, U.; Höfer, M.; Lenz, J. Biotechnological advantages of laboratory-scale solid-state fermentation with fungi. Appl. Microbiol. Biotechnol. 2004, 64, 175-186. [CrossRef] [PubMed]

4. Dashtban, M.; Schraft, H.; Qin, W. Fungal bioconversion of lignocellulosic residues; opportunities \& perspectives. Int. J. Biol. Sci. 2009, 5, 578-595. [CrossRef] [PubMed]

5. Krishna, C. Solid-state fermentation systems-an overview. Crit. Rev. Biotechnol. 2005, 25, 1-30. [CrossRef]

6. Rodriguez-Leon, J.A.; Soccol, C.R.; Pandey, A.; Rodriguez, D.E. Factors Affecting Solid-state Fermentation. In Current Developments in Solid-State Fermentation; Pandey, A., Soccol, C.R., Larroche, C., Eds.; Springer: New York, NY, USA, 2008; pp. 26-47. [CrossRef]

7. Singh nee' Nigam, P.; Pandey, A. (Eds.) Solid-State Fermentation Technology for Bioconversion of Biomass and Agricultural Residues. In Biotechnology for Agro-Industrial Residues Utilisation; Springer: Dordrecht, Netherlands, 2009; pp. 197-221. [CrossRef]

8. Christensen, C.H.; Rass-Hansen, J.; Marsden, C.C.; Taarning, E.; Egeblad, K. The Renewable Chemicals Industry. Chemsuschem. 2008, 1, 283-289. [CrossRef]

9. Bozell, J.J. Feedstocks for the Future-Biorefinery Production of Chemicals from Renewable Carbon. CLEAN Soil Air Water 2008, 36, 641-647. [CrossRef]

10. Willke, T.; Vorlop, K.D. Industrial bioconversion of renewable resources as an alternative to conventional chemistry. Appl. Microbiol. Biotechnol. 2004, 66, 131-142. [CrossRef]

11. Gallezot, P. Conversion of biomass to selected chemical products. Chem. Soc. Rev. 2012, 41, 1538-1558. [CrossRef]

12. Werpy, T.; Holladay, J.; White, J. Top Value Added Chemicals From Biomass: I. Results of Screening for Potential Candidates from Sugars and Synthesis Gas. DOE Scientific and Technical Information.; Pacific Northwest National Lab: Richland, WA, USA, 2004; 419907. [CrossRef]

13. Bozell, J.J.; Petersen, G.R. Technology development for the production of biobased products from biorefinery carbohydrates-the US Department of Energy's 'Top 10' revisited. Green Chem. 2010, 12, 539. [CrossRef]

14. Magnuson, J.K.; Lasure, L.L. Organic Acid Production by Filamentous Fungi. In Advances in Fungal Biotechnology for Industry, Agriculture, and Medicine; Tkacz, J.S., Lange, L., Eds.; Springer: New York, NY, USA, 2004; pp. 307-340. [CrossRef]

15. Goldberg, I.; Rokem, J.S.; Pines, O. Organic acids: Old metabolites, new themes. J. Chem. Technol. Biotechnol. 2006, 81, 1601-1611. [CrossRef]

16. Tsao, G.T.; Cao, N.J.; Du, J.; Gong, C.S. Production of multifunctional organic acids from renewable resources. Adv. Biochem. Eng. Biotechnol. 1999, 65, 243-280. [CrossRef] [PubMed]

17. Liaud, N.; Giniés, C.; Navarro, D.; Fabre, N.; Crapart, S.; Gimbert, I.H.; Levasseur, A.; Raouche, S.; Sigoillot, J.C. Exploring fungal biodiversity: organic acid production by 66 strains of filamentous fungi. Fungal Biol. Biotechnol. 2014, 1, 1. [CrossRef] 
18. Roa Engel, C.A.; Straathof, A.J.J.; Zijlmans, T.W.; Van Gulik, W.M.; Van Der Wielen, L.A.M. Fumaric acid production by fermentation. Appl. Microbiol. Biotechnol. 2008, 78, 379-389. [CrossRef] [PubMed]

19. Xu, Q.; Li, S.; Huang, H.; Wen, J. Key technologies for the industrial production of fumaric acid by fermentation. Biotechnol. Adv. 2012, 30, 1685-1696. [CrossRef]

20. Yahiro, K.; Shibata, S.; Jia, S.R.; Park, W.; Okabe, M. Efficient itaconic acid production from raw corn starch. J. Ferment. Bioeng. 1997, 84, 375-377. [CrossRef]

21. Hevekerl, A.; Kuenz, A.; Vorlop, K.D. Filamentous fungi in microtiter plates-An easy way to optimize itaconic acid production with Aspergillus terreus. Appl. Microbiol. Biotechnol. 2014, 98, 6983-6989. [CrossRef]

22. Willke, T.; Vorlop, K.D. Biotechnological production of itaconic acid. Appl. Microbiol. Biotechnol. 2001, 56, 289-295. [CrossRef]

23. Kanamasa, S.; Dwiarti, L.; Okabe, M.; Park, E.Y. Cloning and functional characterization of the cis-aconitic acid decarboxylase (CAD) gene from Aspergillus terreus. Appl. Microbiol. Biotechnol. 2008, 80, 223-229. [CrossRef]

24. Okabe, M.; Lies, D.; Kanamasa, S.; Park, E.Y. Biotechnological production of itaconic acid and its biosynthesis in Aspergillus terreus. Appl. Microbiol. Biotechnol. 2009, 84, 597-606. [CrossRef]

25. Begum, M.F.; Alimon, A.R. Bioconversion and saccharification of some lignocellulosic wastes by Aspergillus oryzae ITCC-4857.01 for fermentable sugar production. Electron. J. Biotechnol. 2011, 14, 5. [CrossRef]

26. Tsai, Y.C.; Huang, M.C.; Lin, S.F.; Su, Y.C. Method for the production of itaconic acid using Aspergillus terreus solid state fermentation. U.S. Patent 6171831, 09 January 2001.

27. West, T.P. Fumaric acid production by Rhizopus oryzae on corn distillers' grains with solubles. Res. J. Microbiol. 2008, 3, 35-40. [CrossRef]

28. Jiménez-Quero, A.; Pollet, E.; Zhao, M.; Marchioni, E.; Averous, L.; Phalip, V. Itaconic and fumaric acid production from biomass hydrolysates by Aspergillus strains. J. Microbiol. Biotechnol. 2016, 26, 1557-1565. [CrossRef] [PubMed]

29. Jiménez-Quero, A.; Pollet, E.; Zhao, M.; Marchioni, E.; Averous, L.; Phalip, V. Fungal fermentation of lignocellulosic biomass for itaconic and fumaric acid production. J. Microbiol. Biotechnol. 2017, 27, 1-8. [CrossRef] [PubMed]

30. Te Biesebeke, R.; Ruijter, G.; Rahardjo, Y.S.P.; Hoogschagen, M.J.; Heerikhuisen, M.; Levin, A.; van Driel, K.G.A.; Schutyser, M.A.I.; Dijksterhuis, J.; Zhu, Y.; et al. Aspergillus oryzae in solid-state and submerged fermentations. Progress report on a multi-disciplinary project. Fems Yeast Res. 2002, 2, 245-248. [CrossRef] [PubMed]

31. Ummalyma, S.B.; Supriya, R.D.; Sindhu, R.; Binod, P.; Nair, R.B.; Pandey, A.; Gnansounou, E. Biological pretreatment of lignocellulosic biomass-Current trends and future perspectives. In Second and Third Generation of Feedstocks; Elsevier: Alpharetta, GA, USA, 2019; pp. 197-212. [CrossRef]

32. Kumar, R.; Singh, S.; Singh, O.V. Bioconversion of lignocellulosic biomass: biochemical and molecular perspectives. J. Ind. Microbiol. Biotechnol. 2008, 35, 377-391. [CrossRef]

33. Gervais, P.; Molin, P. The role of water in solid-state fermentation. Biochem. Eng. J. 2003, 13, 85-101. [CrossRef]

34. Mondala, A.H. Direct fungal fermentation of lignocellulosic biomass into itaconic, fumaric, and malic acids: current and future prospects. J. Ind. Microbiol. Biotechnol. 2015, 42, 487-506. [CrossRef]

35. Wang, J.; Chen, X.; Chio, C.; Yang, C.; Su, E.; Jin, Y.; Qin, W. Delignification overmatches hemicellulose removal for improving hydrolysis of wheat straw using the enzyme cocktail from Aspergillus niger. Bioresour. Technol. 2019, 274, 459-467. [CrossRef]

36. Sandhya, C.; Sumantha, J.; Szakacs, G.; Pandey, A. Comparative evaluation of neutral protease production by Aspergillus oryzae in submerged and solid-state fermentation. Process Biochem. 2005, 40, 2689-2694. [CrossRef]

37. Koser, S.; Anwar, Z.; Iqbal, Z.; Anjum, A.; Aqil, T.; Mehmood, S.; Irshad, M. Utilization of Aspergillus oryzae to produce pectin lyase from various agro-industrial residues. J. Radiat. Res. Appl. Sci. 2014, 7, 327-332. [CrossRef]

38. Viniegra-González, G.; Favela-Torres, E.; Aguilar, C.N.; de Rómero-Gomez, S.J.; Díaz-Godínez, G.; Augur, C. Advantages of fungal enzyme production in solid state over liquid fermentation systems. Biochem. Eng. J. 2003, 13, 157-167. [CrossRef] 
39. Ayyachamy, M.; Gupta, V.K.; Cliffe, F.E.; Tuohy, M.G. Enzymatic Saccharification of Lignocellulosic Biomass. In Laboratory Protocols in Fungal Biology; Gupta, V.K., Tuohy, M.G., Ayyachamy, M., Turner, K.M., O’Donovan, A., Eds.; Springer: New York, NY, USA, 2013; pp. 475-481. [CrossRef]

40. Zhao, C.; Chen, S.; Fang, H. Consolidated bioprocessing of lignocellulosic biomass to itaconic acid by metabolically engineering Neurospora crassa. Appl. Microbiol. Biotechnol. 2018, 102, 9577-9584. [CrossRef] [PubMed]

41. Tehrani, H.H.; Tharmasothirajan, A.; Track, E.; Blank, L.M.; Wierckx, N. Engineering the morphology and metabolism of $\mathrm{pH}$ tolerant Ustilago cynodontis for efficient itaconic acid production. Metab. Eng. 2019, 54, 293-300. [CrossRef] [PubMed]

42. Nemestóthy, N.; Bakonyi, P.; Komáromy, P.; Bélafi-Bakó, K. Evaluating aeration and stirring effects to improve itaconic acid production from glucose using Aspergillus terreus. Biotechnol. Lett. 2019, 41, 1383-1389. [CrossRef]

43. Molnar, A.P.; Németh, Z.; Kollath, I.S.; Fekete, E.; Flipphi, M.; Ag, N.; Karaffa, L. High oxygen tension increases itaconic acid accumulation, glucose consumption, and the expression and activity of alternative oxidase in Aspergillus terreus. Appl. Microbiol. Biotechnol. 2018, 102, 8799-8808. [CrossRef]

44. Chenyu Du, A.A. Fermentative Itaconic Acid Production. J. Biodivers. Bioprospecting Dev. 2014, 1, 2. [CrossRef]

45. Bradford, M.M. A rapid and sensitive method for the quantitation of microgram quantities of protein utilizing the principle of protein-dye binding. Anal. Biochem. 1976, 72, 248-254. [CrossRef]

Sample Availability: Not available.

(C) 2020 by the authors. Licensee MDPI, Basel, Switzerland. This article is an open access article distributed under the terms and conditions of the Creative Commons Attribution (CC BY) license (http://creativecommons.org/licenses/by/4.0/). 